Journal of Applied Business, Taxation and Economics Research (JABTER)

Vol. 1, No. 2, 2021 (Page: 243-256)

DOI: $10.54408 /$ jabter.v1i3.48

E-ISSN 2808-263X

\title{
The Effect of Managerial Ownership and Institutional Ownership on Sustainability Reporting and Their Impact on Earning Management
}

\author{
Listia Aulia Indy ${ }^{1 *}$,Lia Uzliawati ${ }^{2}$, Windu Mulyasari ${ }^{3}$ \\ University of Sultan Ageng Tirtayasa $a^{1^{*}, 2,3}$ \\ Corresponding Author: listiaa08@gmail.com
}

Keywords: Managerial Ownership, Institutional Ownership, Sustainability Reporting, Earning Management

\begin{abstract}
:
The purpose of this study is to examine the effect of managerial ownership and institutional ownership on sustainability reporting and their impact on earnings management. This research is a type of quantitative research using purposive sampling method as a sampling method. The data collected comes from the annual reports of companies in the mining sector and the basic and chemical industry sectors listed on the Indonesia Stock Exchange from 2015 to 2019, with data analysis techniques using IBM SPSS V.20 software for windows. The results showed that managerial ownership had no effect on sustainability reporting, while institutional ownership had no effect on sustainability reporting. Sustainability reporting has a negative effect on earnings management.
\end{abstract}




\section{Introduction}

The one way that is often used to make financial statements to look good in the eyes of stakeholders is to do earnings management. The earnings management is a behavior that does not comply with the rules or deviates (dysfunctional behavior) due to a tendency to pay more attention to earnings, especially by managers because their performance is measured based on that information (Widyaningdyah, 1997). The purpose of earnings management is to provide self-protection for managers and the company to anticipate unexpected events for the benefit of the parties involved in the company.

Watt and Zimmerman in Suryani and Herianti (2015) define earnings management as a manager's action in using accounting policies to report accounting numbers that are not in accordance with the actual economic conditions of the company and mislead investors in making economic decisions with the profit figures. The phenomenon that occurs in Indonesia regarding cases of earnings management violations is PT Timah Tbk. This company is engaged in the mining sector. One of them is the case of PT Timah (Persero) Tbk allegedly providing fictitious financial statements in the first semester of 2015. This fictitious financial reporting activity was carried out to cover up the worrying financial performance of PT Timah.

The inability of PT Timah's board of directors to get out of the loss trap has resulted in the handover of $80 \%$ of PT Timah's mining area to business partners. If referring to the real conditions that occurred at PT Timah, Ali believes that the first semester 2015 financial statements of PT Timah (Persero) Tbk are fictitious. Because according to him, in the first semester of 2015 PT Timah's operating profit had suffered a loss of Rp. 59 billion (Agustina and Suryani, 2018).

In this regard, information plays an important role. Not only information related to financial statements but also information on all activities and practices of the company. Disclosure of social and environmental responsibility is one of the company's business strategies to increase profits.

The Companies that implement Corporate Social Responsibility expect a positive response from market players such as investors and creditors who will be able to increase the value of the company. CSR activities can be realized in the form of sustainability reporting that focuses on economic, social, environmental aspects (Herbert and Mark, 2019).

Sustainability report or better known as sustainable financial reporting is an important issue in the development process of a company. The government has difficulty in monitoring and measuring the company's CSR program commitments due to the lack of analysis of reports made by companies. This reason has triggered the creation of a special regulation that regulates the sustainability report in detail and measurable detail. The Several companies are required by the OJK to make a sustainability report which will later accompany the annual report.

An Institutional share ownership or institutional investors have the right to control the management through an effective monitoring process so as to encourage management performance to prioritize the interests of other parties (stakeholders). This means that large 
institutional share ownership can encourage the quality of information and disclosure of sustainability reports by companies. (Aliniar \& Wahyuni, 2017). One consequence of implementing the principles of Corporate Governance is that companies cannot only think about financial performance but must also include an assessment of their social and environmental performance (Daniri, 2014). The company then discloses its social and environmental responsibility activities through sustainability reports to meet stakeholder interests.

The Research conducted by Amar and Chakroun (2018) analysis of the impact of corporate social responsibility on earnings management is based on the ISO 26000 analytical framework, which stipulates that companies must respect the seven dimensions of society. The negative impact of corporate social responsibility on earnings management, indicates that companies with greater corporate social responsibility perform less earnings management.

These observations are in line with previous works such as those published by (Kim et al., 2012); (Ferrero, 2016); (Gras-Gil et al., 2016). In addition, corporate governance, respect for human rights, good environmental management and meeting consumer expectations have a significant meaning and cannot have a negative impact on earnings management. On the other hand, labor relations and conditions, fairness of practice and community involvement have no effect on earnings management, and analyze the impact of sustainability reporting on earnings management. However, there is a difference from previous research, namely this research only examines the ownership aspect, namely managerial ownership and institutional ownership. The researcher chose companies in the mining sector and the basic and chemical industrial sector as samples in this study because these sectors have the most impact on the environment.

Freeman et al (2010) define a stakeholder as an organization, group, or individual who can be influenced and influence the goals of the organization. This definition indicates a twoway impact relationship between an organization and its stakeholders. Stakeholder theory has been at the core of sustainability accounting and reporting research because it emphasizes broader organizational accountability. This theory asserts that organizational accountability goes beyond providing accounts to shareholders and includes all individuals and groups affected by their decisions. (Kaur \& Lodhia, 2018).

The relationship with the variables in this study is because stakeholder theory shows a two-way impact relationship between the organization and its stakeholders. The involvement of stakeholders, both managerial and institutional, is very important in making decisions to achieve organizational performance. The Companies that disclose sustainability reporting expect a positive response from stakeholders. Stakeholder theory also asserts that accountability is influenced by stakeholder decisions.

According to Aziz (2014) Good Corporate Governance (GCG) is corporate governance that has a broader agenda in the future. The focus of corporate accountability which was originally still concentrated or oriented to shareholders (stakeholders), is now wider and for corporate governance must also pay attention to stakeholder interests. As a result of this 
paradigm shift, corporate governance must consider issues such as corporate social responsibility (CSR).

According to the Finance Committee on Corporate Governance, corporate governance is a process and structure used to direct and manage business and company activities towards increasing business growth and corporate accountability (Aziz, 2014). In general, sustainability reporting is described as an information management and accounting method that aims to create and provide high quality information to demonstrate the organization's progress towards its sustainability goals. Sustainability reporting is described as a formal communication tool to reveal an organization's sustainability performance (Kaur \& Lodhia, 2018). The sustainability report describes the company's sense of responsibility to the community which can be seen in the aspects reported and is also a source of information for stakeholders to make decisions (Pratiwi, 2013). The company is responsible to stakeholders consisting of investors, consumers, employees, distributors and the public. Sustainability consists of three aspects, people-social; planet-environment; and profit-economics. So according to Elkington the company must be responsible for the positive and negative impacts caused to economic, social and environmental aspects (Hasanah et al., 2017).

Earning management is the manager's action to increase or decrease the reported profit of the unit that is his responsibility but has no relationship with the increase or decrease in the company's profitability in the long term (Fischer and Rosenzweig, 1995). However, Gumanti (2000) says that earnings management is closely related to the level of earnings (earnings) or business performance of an organization. Management achievements and the provision of incentives received are always associated with the profits earned. Therefore, management will try to report its financial statements as good as possible, so that the profits shown are constant and avoid information about losses in order to show their achievements. Profit information obtained by stakeholders will be used as a decision maker by considering the company's earnings power.

Managers as owners and managers will act for their investments as well as for the company. The greater the managerial ownership in a company, the more it will encourage company managers to make more efforts to provide benefits to the company (Aniktia, 2015). This illustrates the existence of a two-way impact relationship described in Stakeholder theory between the organization and its stakeholders. First, stakeholders can influence organizational goals which means that organizational performance can benefit from the activities and participation of stakeholders (Gao and Zhang, 2006). Second, stakeholders are affected by the achievement of organizational goals and this impact legitimizes stakeholders' right to stakeholder engagement (Gao and Zhang, 2006). One of these efforts is to disclose the sustainability report. Based on this explanation, the first research hypothesis proposed is as follows:

H1: The managerial ownership affects sustainability reporting

The large shareholdings have the ability to oversee management decision making. The existence of institutional investors is expected to support the disclosure of sustainability 
reports as a form of corporate communication to stakeholders that the company is responsible for its business activities.

According to Aliniar and Wahyuni (2017), the results of the test and discussion are that the proportion of institutional share ownership has a significant positive effect on the quality of disclosure of the sustainability report. This is in line with research conducted by Nurrahman (2013) which found that institutional ownership has an influence on the disclosure of sustainability reports. Based on this explanation, the second research hypothesis proposed is as follows:

H2: An Institutional ownership has an effect on Sustainability Reporting.

The companies usually have controlling shareholders Breton and Schatt (2003), it is possible that managers of socially responsible companies issue more transparent and reliable financial reports to meet the expectations and interests of their reputation stakeholders (Kim et al., 2012). They are less likely to manage earnings because they are not trying to hide adverse earnings. This idea is based on the myopia avoidance hypothesis. (Ferrero, 2016); (Gras-Gil et al., 2016), expect that socially responsible firms have low incentives to manage earnings. The above discussion leads us to formulate the following hypotheses:

H3: Sustainability reporting has a negative effect on Earning Management.

\section{Research Methods}

Population and Sample

This research is a quantitative study using mining sector companies and basic and chemical industry sectors listed on the Indonesia Stock Exchange (IDX) for the 2015-2019 period as the population of the study. Meanwhile, the sampling was carried out by purposive sampling method with the aim of obtaining a representative sample in accordance with the specified criteria. Based on the purposive sampling method, several companies were selected, namely 5 mining sector companies in five years of observation and 11 basic and chemical industrial sector companies in five years of observation, so that the total number of samples was 80 observations.

\section{The Data Types and Sources}

The data used in this study is secondary data in the form of annual reports and sustainability reporting for the 2015-2019 period obtained from the Indonesia Stock Exchange available at www.idx.co.id. Data were collected using library research and field research techniques. Data collected using library research techniques, namely this data is obtained through documents, books or other scientific writings, with the aim of completing secondary data in the field. Meanwhile, field research is a data collection technique where the data is obtained from the internet www.idx.co.id for companies listed on the Indonesia Stock Exchange (IDX) for the 2015-2019 period. 
The Data Types and Sources

The data obtained were then analyzed using SPSS 20 software. The data analysis method uses multiple linear regression analysis for the purpose of estimating and predicting the population mean or the average value of the dependent variable based on the known value of the Independent variable.

In addition, the Spearman correlation test is also used with the aim of knowing the relationship between the independent variable and the dependent variable. The decision making of this test is simple, namely by looking at the Pearson correlation, if the Pearson correlation value is equal to 0 , it means that there is no relationship between variables.

Meanwhile, if the Pearson correlation value is not equal to 0 , it means that there is a relationship between variables. In addition, if the value is positive, it means that there is a positive relationship between the variables and if the value is negative, then there is a negative relationship between the variables.

\section{Result and Discussion}

Deskriptif Statistic Analysis

The following is a table of descriptive statistical results for the entire sample during the 2015-2019 period:

Table 1. Statistic Deslriptif

\begin{tabular}{lrrrrr}
\hline & $\mathrm{N}$ & Minimum & Maximum & \multicolumn{1}{c}{ Mean } & \multicolumn{1}{c}{ Std. Deviation } \\
\hline $\begin{array}{l}\text { Managerial Ownership } \\
\text { (X1) }\end{array}$ & 80 & 0.000 & 149.555 & 11.81521 & 31.207985 \\
$\begin{array}{l}\text { Institution Ownership } \\
\text { (X2) }\end{array}$ & 80 & 0.276 & 971316.008 & 58072.28705 & 225627.804567 \\
$\begin{array}{l}\text { Suistainability } \\
\text { Reporting (Y1) }\end{array}$ & 80 & 0.008 & 0.571 & 0.17326 & 0.146966 \\
$\begin{array}{l}\text { Earning Management } \\
\text { (Y2) }\end{array}$ & 80 & -0.460 & 0.437 & 0.02158 & 0.163824 \\
$\quad$ Valid N (listwise) & 80 & & & & \\
Sources: SPSS Resul Data(2021) & & & & & \\
\end{tabular}

Based on table 1, it can be seen that the dependent variable, namely Earning Management (EM) has an average value of 0.02158 . This indicates that in the mining sector companies and companies in the basic and chemical industry sectors, Earning Management occurs. While the other dependent variable, namely Sustainability Reporting (SR) has a minimum value of 0.008 owned by the company Impack Pratama Industri Tbk at 2016.

This shows that the company has low Sustainability Reporting. Furthermore, the maximum value of 0.571 is owned by the Bukit Asam Tbk company in 2019. This shows that the company has a high Sustainability Reporting. The independent variable, namely Managerial Ownership (KM) has an average value of 31.207985. 
The minimum value is 0.00002 which is owned by the Copper Mulia Semanan Tbk company. In 2016 this shows that the company has low managerial ownership. While the maximum value of 149.555 owned by Chandra Asri Petrochemical Tbk in 2019 shows that the company has high managerial ownership. The standard deviation value is 31.207985.

Another independent variable, namely Institutional Ownership (KI) has an average value of 58072,28705 . The minimum value of 0.276 owned by the company Barito Pacific Tbk. in 2019 this shows that the company has low institutional ownership. While the maximum value of 971316.008 owned by the Bukit Asam Tbk company in 2019, this shows that the company has high institutional ownership.

\section{Classical Assumption Test}

Normality Test Results

The results of the normality test show that the model 1 variable studied is normal because of the Asymp value. Sig. (2-tailed) with a dependent sustainability reporting of 0.340 $>$ alpha 0.05 , so it is stated that the data comes from a normally distributed population. While the model 2 variables studied are normal because of the Asymp value. Sig. (2-tailed) with dependent earnings management of $0.210>$ alpha 0.05 , so it is stated that the data comes from a population that is normally distributed.

\section{Multicollinearity Test Results}

A low tolerance value is the same as a high VIF (Variance Inflation Factors).

The cutoff value commonly used to indicate the presence of multicollinearity is the Tolerance value $<0.01$ or the same as VIF $>10$ (Ghozali, 2013).

The results of the multicollinearity test on models 1 and 2 are presented as follows.

Table 2. Model 1 Multicollinearity Test Results

\begin{tabular}{cccc}
\hline Variabel & $\begin{array}{c}\text { Tolerance } \\
\text { Value }\end{array}$ & VIF Value & Conclusion \\
\hline $\begin{array}{c}\text { Managerial Ownership } \\
(\mathrm{X} 1)\end{array}$ & 0,989 & 1,011 & $\begin{array}{c}\text { There are no } \\
\text { symptoms of } \\
\text { Institution Ownership } \\
\text { (X2) }\end{array}$ \\
$\begin{array}{c}\text { multicollinearity } \\
\text { Sources: SPSS result data (2021) }\end{array}$ & 0,989 & 1,011 & \\
\hline
\end{tabular}

Table 3. Model 1 Multicollinearity Test Results

\begin{tabular}{cccl}
\hline Variabel & $\begin{array}{c}\text { Tolerance } \\
\text { Value }\end{array}$ & Nilai VIF & Conclusion \\
& 1,000 & 1,000 & $\begin{array}{l}\text { There are no } \\
\text { symptoms of } \\
\text { Earning Management }(\mathrm{Y} 2)\end{array}$ \\
& & & multicollinearity \\
\hline
\end{tabular}


Sources: SPSS Result data (2021)

Based on table 1, it can be seen that there is no multicollinearity in the regression model used to test the hypothesis. The results of the tolerance test show that there is no independent variable that has a tolerance value of less than $0.10(10 \%)$. The results of the VIF calculation also show that there is no single independent variable that has a VIF value of more than 10.

While table 2 shows that there is no multicollinearity in the regression model used to test the hypothesis. The results of the tolerance test show that there is no independent variable that has a tolerance value of less than $0.10(10 \%)$.

\section{Determination Efficiency Test}

The results of the VIF calculation also show that there is no single independent variable that has a VIF value of more than 10. This test aims to determine the best level of accuracy in a regression analysis. The results of the statistical calculation of model 1 , the value of the coefficient of determination ( $R$ square) of this research model is 0.407 or $40.7 \%$. It means that the independent variable in this study is able to explain its influence on the dependent variable by $40.7 \%$, and the rest is influenced by other variables not examined in this research model.

Based on the results of testing model 2 the value of the coefficient of determination ( $R$ square) of this research model is 0.076 or $7.6 \%$. It means that the independent variable in this study is able to explain its effect on the dependent variable of $7.6 \%$, and the rest is influenced by other variables not examined in this research model.

\section{Simultaneous Significant Test (Statistical Test F)}

The F statistical test criteria were carried out by comparing the significant value with an alpha value of 0.05 . If the sig value $>0.05$ then $\mathrm{Ho}$ is accepted and $\mathrm{Ha}$ is rejected, but if the value is $<0.05$, then $\mathrm{Ho}$ is rejected and $\mathrm{Ha}$ is accepted (Ghozali, 2016).

Based on the results of the statistical test model 1 , it is known that the calculated $\mathrm{F}$ value is $26.407>\mathrm{F}$ Table 3.110 with a significance value of $0.000<0.05$. Thus, it can be concluded that the model used in this study is in a good category and is feasible to use. While the results of the statistical test model 2 , it is known that the calculated $F$ value is $6.450>\mathrm{F}$ Table 3.960 with a significance value of $0.013<0.05$. Thus, it can be concluded that the model used in this study is in a good category and is feasible to use.

\section{Multiple Linear Regression Analysis}

Multiple regression analysis is used to predict the value of the regression coefficient on each variable in the research model. In addition, multiple regression analysis was also used to determine the significance value of each research variable in order to be the basis for testing the hypothesis in this study. The equation for the multiple regression model of 
Sustainability Reporting (Variable Y1), Managerial Ownership (Variable X1), and Institutional Ownership (Variable X2).

The results of multiple regression analysis can be seen in the following table

Table 4. Multiple Regression Analysis

\begin{tabular}{lccc}
\hline & $\mathrm{B}$ & $\mathrm{T}$ & Sig \\
\hline (Constant) & 0,156 & 11,127 & 0.000 \\
Managerial & $-0,001$ & $-1,372$ & $0,174^{* * *}$ \\
Ownership(X1) & & & \\
Institution Ownership & $4.164 \mathrm{E}-007$ & 7,242 & $0,000^{*}$ \\
(X2) & 0,407 & & \\
R Square & & \\
\hline \multicolumn{2}{l}{ Sources: SPSS result data (2021) }
\end{tabular}

The linear equation of the result is:

$$
\mathrm{SR}=0,156+(-0,001)+4.164 \mathrm{E}-007
$$

a. Based on the regression results, it is known that the managerial ownership variable has no effect on Sustainability Reporting with a t-count value of -1.372 with a significance value of $0.174>0.1$.

b. Thus it can be concluded that the test is able to prove that Managerial Ownership has no effect on Sustainability Reporting. Thus, the first hypothesis in this study was rejected.

Institutional Ownership variable has an effect on the t value of 7.242 with a significance value of $0.000<0.01$. This means, the test is able to prove that Managerial Ownership has an effect on Sustainability Reporting. Thus, the second hypothesis in this study was accepted.

Simple Regression Analysis

The equation for the simple regression model is the Earning Management variable (Variable Y) and the Sustainability Reporting variable (Variable X).

The results of simple regression analysis can be seen in the following table:

Table 5. Simple Regression Analysis

\begin{tabular}{lccc}
\hline & B & T & Sig. \\
\hline (Constant) & 0,075 & 2,727 & $0.008^{*}$ \\
Sustainability & $-0,308$ & $-2,540$ & $0,013^{* *}$ \\
Reporting (Y1) & & & \\
R Square & 0,076 & \\
F & 6,450 & $0,013^{* *}$ \\
\hline
\end{tabular}


Based on table 5, it is proven that the Sustainability Reporting variable has an effect on Earning Management with a t value of -2.540 with a significance value of $0.013<0.05$. Thus it can be concluded that the test is able to prove that Sustainability Reporting has a negative effect on Earning Management. Therefore, the third hypothesis in this study is accepted.

\section{Spearman Correlation Test}

If the Spearman Correlation is equal to 0 , it means that there is no relationship between the variables, and if the value is not equal to 0 , it means that there is a relationship between the variables. The following are the results of the Correlation test (Spearman, 1987).

Table 6. Spearman Correlation Test Results Table

\begin{tabular}{lrrrr}
\hline \multicolumn{5}{c}{ Spearman Correlations Matrix } \\
\hline & 1 & 2 & 3 & 4 \\
1. Managerial ownership & 1 & & & \\
2. Institusional Ownership & 0,106 & 1 & & \\
3. Sustainability Reporting & $-0,053$ & 0,626 & 1 & \\
4. Earning Management & 0,018 & $-0,132$ & $-0,276$ & 1 \\
\hline Sig *0,01; ${ }^{*} 0,05$ & & & & \\
\hline
\end{tabular}

Sumber: SPSS Result Data (2021)

Based on table 6, it is known that the variable of institutional ownership and managerial ownership has a spearman correlation value of 0.106 , meaning that there is a positive relationship between the two variables. The sustainability Reporting and Managerial Ownership variables have a Spearman correlation value of -0.053 , meaning that there is a negative relationship between the two variables. The variables of Sustainability Reporting and Institutional Ownership have a Spearman correlation value of 0.626 , meaning that there is a positive relationship between the two variables. The Earning Management and Managerial Ownership variables have a Spearman correlation value of 0.018 , meaning that there is a positive relationship between the two variables.

The earning Management and Institutional Ownership variables have a Spearman correlation value of -0.132 , meaning that there is a negative relationship between the two variables. The Earning Management and Sustainability Reporting variables have a Spearman correlation value of -0.276 , meaning that there is a negative relationship between the two variables. 
Discussion

The Effect of Managerial Ownership on Sustainability Reporting

The first hypothesis predicts that managerial ownership has an effect on Sustainability Reporting, but the results of hypothesis testing in this study show different results, that managerial ownership has no effect on sustainability reporting. Stakeholder theory explains that the involvement of stakeholders, one of which is managerial, is very important to achieve company goals. The more managerial ownership in the company, it will increase the disclosure of sustainability reporting. However, the results in this study are not in line with this theory. Where the results of this study indicate managerial ownership in the company does not increase the disclosure of sustainability reporting.

The researcher found that managerial ownership in the companies studied was still very small and not all companies had shares held by the managers. Based on this, it can be said that companies in the mining sector as well as companies in the basic and chemical industry sector do not have supervision from management that are more related to activities and disclosure of sustainability reporting because the number of managerial ownership is still small. Therefore, managers have an obligation to think about how a company can develop because managers are people who regulate a management process both in preparing financial reports and other management processes.

This study is in line with research conducted by Aniktia (2015) which says that managerial ownership does not affect the disclosure of sustainability reporting because there are still many company managements who do not have share ownership in managed companies or have small shares. According to Nurrahman (2013) the relatively small managerial ownership causes managers to not be able to maximize the value of the company through the disclosure of sustainability reporting. In addition, the results of research by Nurrahman (2013) also concluded that managerial ownership has no effect on sustainability reporting

The Effect of Institutional Ownership on Sustainability Reporting

The second hypothesis predicts that institutional ownership has an effect on sustainability reporting and the results of this study indicate that institutional ownership has an effect on sustainability reporting. Based on stakeholder theory, institutional ownership has the right to control the management through an effective monitoring process.

The results of this study are in line with the theory, where institutional ownership has an effect on the disclosure of Sustainability Reporting. In addition, other research that is in line with this research is the research conducted by Aliniar and Wahyuni (2017) which states that institutional ownership has an effect on sustainability reporting.

Sustainability Reporting On Earning Management

The third hypothesis predicts that sustainability reporting has a negative effect on earnings management and the results of this study indicate that sustainability reporting has 
a negative effect on earnings management, because the more companies involved in the practice of sustainability reporting, the fewer companies do earning management.

Based on stakeholder theory, the accepted paradigm to explain why companies engage in social and environmental activities as a strategy to maximize long-term return on investment and sustainable business success. The interests of each stakeholder group are studied and incorporated into the company's strategy. The Company managers will carry out transparency by including more information needed by outside parties in the disclosure of sustainability reporting. Transparency by the company will tend to make managers not do earnings management.

The author found in this study that the mining sector company was seen at PT Bukit Asam in 2019. Where the company makes a fairly high disclosure of sustainability reporting that is equal to 0.571 and performs earnings management which is quite low at -0.2. As well as in the basic and chemical industrial sector companies seen in PT Indo Acidatama in 2016. Where the company discloses sustainability reporting which is quite high, namely 0.534 and performs earnings management which is quite low, namely -0.46 . This shows that the higher the company is involved in the practice of disclosure of sustainability reporting, the less companies do earnings management.

The results of this test show conformity with the results of Amar and Chakroun (2018) who concluded that sustainability reporting has a negative effect on earnings management. Another study, Gras-Gil et al (2016), stated that sustainability reporting has a negative effect on earnings management. These results also provide the conclusion that the manager works in accordance with the interests of parties outside the company. The external parties referred to in this study are institutional parties as stakeholders who have greater interests than the manager. This is because the share ownership is higher. Thus, it can be concluded that institutional ownership affects the disclosure of sustainability reporting and ultimately has an impact on reducing earning management practices.

\section{Conclusion}

Based on the description of the results and discussion, it can be concluded that the managerial ownership variable has no effect on Sustainability Reporting. Based on this, it can be said that companies in the mining sector as well as companies in the basic and chemical industry sector do not have supervision from management that are more related to activities and disclosure of sustainability reporting because the number of managerial ownership is still small. Because, the higher the managerial ownership, the higher the quality of sustainability reporting disclosure.

Furthermore, it is known that the institutional ownership variable has an effect on Sustainability Reporting, which means that the higher the institutional ownership, the higher the quality of sustainability reporting disclosure will be. While the third hypothesis is accepted, namely the sustainability reporting variable has a negative effect on Earning Management. With sustainability reporting, company managers will try to 
publish more transparent and reliable financial reports to meet the expectations and interests of stakeholders.

\section{References}

Agustina, Y. ., \& Suryani, E. (2018). Pengaruh Ukuran Perusahaan, Umur Perusahaan, Leverage, Dan Profitabilitas Terhadap Manajemen Laba (Studi Pada Perusahaan Pertambangan yang Terdaftar di Bursa Efek Indonesia Periode 2014-2016). Jurnal ASET (Akuntansi Riset), 10(1), 71-82. https://doi.org/10.17509/jaset.v10i1.12571

Aliniar, D., \& Wahyuni, S. (2017). Pengaruh Mekanisme Good Corporate Governance (Gcg) Dan Ukuran Perusahaan Terhadap Kualitas Pengungkapan Sustainability Report Pada Perusahaan Terdaftar Di Bei. Jurnal Universitas Muhammadiyah Purwekerto, 15(1), 2641.

Amar, B. A., \& Chakroun, S. (2018). Do dimensions of corporate social responsibility affect earnings management?: Evidence from France. Journal of Financial Reporting and Accounting, 16(2), 348-370.

Aniktia, R. M. K. (2015). Pengaruh Mekaniseme Good Corporate Governance Dan Kinerja Keuangan Terhadap Pengungkapan Sustainability Report. Accounting Analysis Journal, 4(3), 1-10. https://doi.org/10.15294/aaj.v4i3.8303

Aziz, A. (2014). Analisis Pengaruh Good Corporate Governance (Gcg) Terhadap Kualitas Pengungkapan Sustainability Report. Jurnal Audit Dan Akuntansi Fakultas Ekonomi Universitas Tanjungpura, 3(2), 65-84.

Breton, G., \& Schatt, A. (2003). Manipulation comptable:les dirigeants et les autres parties prenantes. Revue Du Financier, 4(2), 112-115.

Daniri, M, A. (2014). Lead By GCG. Gagas Bisnis Indonesia.

Edison, A. (2017). Struktur Kepemilikan Asing, Kepemilikan Institusional Dan Kepemilikan Manajerial Pengaruhnya Terhadap Luas Pengungkapan Corporate Social Responsibility (Csr). Jurnal Bisma, 11(2), 164-268.

Ferrero. (2016). Today Michelle Will Be a Princess. Andrews McMeel Publishing, . 44(0), 149.

Fischer, M., \& Rosenzweig, K. (1995). Attitudes of students and accounting practitioners concerning the ethical acceptability of earnings management. Journal of Business Ethics, 14(6), 433-444.

Freeman, R. E., Harrison, J. S., Wicks, A. C., Parmar, B., \& de Colle, S. (2010). Stakeholder theory: The state of the art. The Academy of Management Annals, 4(1).

Gao, S. S., \& Zhang, J. J. (2006). Stakeholder engagement, social auditing and corporate sustainability. Business Process Management Journal, 12(6), 722-740. https://doi.org/10.1108/14637150610710891

Ghozali, I. (2013). Aplikasi Analisis Multivariate dengan Program IBM SPSS 21 Update PLS Regresi. Badan Penerbit Universitas Diponegoro.

Ghozali, I. (2016). Aplikasi Analisis Multivariete Dengan Program IBM SPSS 23 (Edisi 8). Cetakan ke VIII. Badan Penerbit Universitas Diponegoro. 
Gras-Gil, E., Manzano, P. M., \& Fernández, H. . (2016). Investigating the relationship between corporate social responsibility and earnings management: Evidence from Spain. BRQ Business Research Quarterly, 19(4), 289-299. BRQ Business Research Quarterly, 19(4), 289-299. https://doi.org/10.1016/j.brq.2016.02.002

Gumanti, T. A. (2000). Earnings Management: Suatu Telaah Pustaka. Earnings Management: Suatu Telaah Pustaka. Jurnal Akuntansi Dan Keuangan, 2(2), 104-115.

Hasanah, N., Syam, D., \& Jati, A. W. (2017). Pengaruh Corporate Governance terhadap Pengungkapan Sustainability Report pada Perusahaan di Indonesia. Jurnal Reviu Akuntansi Dan Keuangan, 5(1), 711-720. https://doi.org/10.22219/jrak.v5i1.4992

Herbert, S., \& Mark, G. (2019). The Relationship Between Sustainability Reporting and Integrated Reporting : 2018 Southern African Accounting Association ( SAAA ) National Teaching and Learning and WC004. Southern African Journal of Accountability and Auditing Research, 4(2), 125-142.

Kaur, A \& Lodhia, S. (2018). Stakeholder engagement in sustainability accounting and reporting: A study of Australian local councils. Accounting, Auditing and Accountability Journal, 31(1), 338-368. https://doi.org/10.1108/AAAJ-12-2014-1901

Kim, Y., Park, M. S., \& Wier, B. (2012). Is earnings quality associated with corporate social responsibility? Accounting Review, 87(3), 761-796. https://doi.org/10.2308/accr-10209

Nurrahman, A. (2013). Pengaruh Kepemilikan Manajerial, Kepemilikan Institusional, Dan Kepemilikan Asing Terhadap Praktik Pengungkapan Sustainability Report Diponegoro. Journal of Accounting, 0(0), 273-285.

Pratiwi, K. P. (2013). Environmental Incidents, Pemberitaan Media Dan Praktik Pengungkapan Lingkungan (Environmental Disclosures): Studi Pada Sustainability Report Asia Pulp And Paper. Journal of Accounting, 0(0, 470-481.

Spearman. (1987). Commentary: Spearman's "The proof and measurement of association between two things". International Journal of Epidemiology, 39(5), 1159-1161. https://doi.org/10.1093/ije/dyq200

Suryani, A \& Herianti, E. (2015). Pengaruh Pengungkapan Tanggung Jawab Sosial Perusahaan terhadap Koefisen Respon Laba dan Manajemen Laba (Studi Empiris pada Perusahaan Manufaktur yang Terdaftar di Bursa Efek Indonesia). Simposium Nasional Akuntansi XVIII, 3(2), 1-26.

Widyaningdyah, A. U. (1997). Terhadap Earnings Management Pada Perusahaan Go Public Di Indonesia. Jurnal Akuntansi, 3(1). 